\title{
Problematika Orang Tua dalam Mendampingi Anak pada Pembelajaran Era pandemi Covid-19
}

\author{
Ainun Mustarsyida \\ Universitas Islam Negeri (UIN) Sunan Kalijaga Yogyakarta \\ ainunmustarsyida@gamil.com \\ Erni Munastiwi \\ Universitas Islam Negeri (UIN) Sunan Kalijaga Yogyakarta \\ erni.munastiwi@uin-suka.ac.id
}

\begin{abstract}
This study aims to identify the problems of parents in assisting their children in learning during the COVID-19 pandemic. This study uses a qualitative method with a literature approach where in collecting information and data with documentation techniques and data on relevant matters from various sources in the library such as documents, books, magazines, news. The selection of news or articles can be classified based on discussion of COVID-19 and learning at home. This study was conducted to find various problems experienced by parents during the COVID-19 pandemic. The results of this study found the problems experienced by parents who were researchers divided into three groups, namely technology, mental, and role.
\end{abstract}

Keywords: Parental Problems; Child Facilitators; Learning during the Pandemic.

\begin{abstract}
Abstrak
Penelitian ini bertujuan untuk mengidentifikasi problematika orang tua dalam mendampingi anak-anak mereka melakukan pembelajaran selama masa pandemi COVID-19. Penelitian ini menggunakan metode kualitatif dengan pendekatan kepustakaan dimana dalam mengumpulkan informasi dan data dengan teknik dokumentasi dan data mengenai hal-hal yang relevan dari berbagai macam sumber yang ada di perpustakaan seperti dokumen, buku, majalah, berita. Pemilihan berita atau artikel dapat di klasifikasi berdasarkan pembahasan tentang COVID-19 dan pembelajaran di rumah. Studi
\end{abstract}


ini dilakukan untuk menemukan berbagai problematika yang dialami Orangtua saat masa pandemi COVID-19. Hasil dalam penelitian ini ditemukan problematika yang dialami para orang tua yang peneliti bagi menjadi tiga kelompok, yakni teknologi, mental, dan peran.

Kata Kunci: Problematika Orang Tua; Pendampingan Anak; Pandemi.

\section{Pendahuluan}

Saat ini dunia tengah dilanda sebuah wabah yang berasal dari Wuhan, China. Wabah penyebarannya terus meluas dan bergerak cepat sehingga menyelimuti seluruh dunia, tidak terkecuali Indonesia ini disebut dengan Corona atau COVID-19. Seluruh dunia gencar mengambil langkah untuk menghentikan mata rantai penyebaran, termasuk Indonesia yang mengupayakan social distancing dan phsical distancing. Lemahnya informasi yang didapat warga Indonesia, mengakibatkan pengabaian upaya social distancing maupun phsical distancing. Yang kemudian pemerintah memutuskan kebijakan berupa Lockdown, untuk mencegah terjadinya penularan COVID-19 akibat berkerumun di luar ruangan. ${ }^{1}$ Dengan begitu segala kegiatan masyarakat terhambat karena wabah ini di segala bidang seperti sosial, ekonomi, pariwisata maupun pendidikan. ${ }^{2}$ Edaran pemerintah pada tanggal 18 Maret 2020 terbit dan menjelaskan agar segala macam kegiatan dalam maupun luar ruangan harus ditunda demi pencegahan penyebaran Corona, termasuk kegiatan pembelajaran. ${ }^{3}$

Pembelajaran pada masa pandemi Covid 19 berbeda dengan pembelajaran pada situasi normal. Pembelajaran pada masa pendemi dilakukan melalui pembelajaran jarak jauh atau pembelajaran dari rumah dengan memanfaatkan media online. ${ }^{4}$ Akibatnya, dalam pelaksanaannya ditemukan berbagai problem yang dihadapi guru maupun para orang tua yang mana menggantikan guru dalam menyampaikan pembelajaran di rumah. Analisis problematika pembelajaran dalam masa pandemi ini diharapkan menjadi salah satu sarana mempermudah pembelajaran untuk pengajar, orang tua, maupun untuk murid. Pembelajaran yang optimal bergantung pada orang tua sebagai pembimbing pembelajaran anak di rumah. Dalam penelitain ditemukan bahwa orang tua terlalu sibuk oleh pekerjaan yang berpindah ke rumah (Work From Home), menyebabkan ketidak optimalan pembelajaran pada anak. Sehingga

${ }^{1}$ Dewi Astuti, "Analisis Peran Orang Tua Dalam Meningkatkan Hasil Belajar Siswa Kelas X Smk Muhammadiyah Pontianak,” t.t., 8.

${ }^{2}$ kompas.com pada 23/03/2020

${ }^{3}$ Wahyu Aji Fatma Dewi, "Dampak Covid-19 Terhadap Implementasi Pembelajaran Daring Di Sekolah Dasar" 2, no. 1 (2020): 7.

${ }^{4}$ Sutarto, S., Sari, D. P., \& Fathurrochman, I. (2020). Teacher strategies in online learning to increase students' interest in learning during COVID-19 pandemic. Jurnal Konseling dan Pendidikan, 8(3), 129-137. 
upaya yang dilakukan orang tua sebaiknya meluangkan waktu dalam mengawasi anak dan memberikan bimbingan atau arahan yang lebih baik walaupun di selasela bekerja. Namun, dengan adanya pandemi seperti ini tentu saja kesibukan di rumah semakin bertambah, walaupun kesibukan di luar rumah menjadi berkurang. ${ }^{5}$

Menemukan pembelajaran untuk anak sekolah dasar dapat terlaksana dengan baik apabila terjadi kerjasama yang harmonis antara orang tua, murid, dan pengajar. Dalam proses pembelajaran murid, selain menuntut kreativitas guru dalam memberikan bahan ajar dengan menarik, perlunya pengawasan dan bimbingan terhadap murid. Terutama siswa yang berada di kelas 1 sampai 3 yang mana masih awam dengan penggunaan teknologi, sehingga perlunya pendampingan orang tua saat penggunaannya. ${ }^{6}$ Wawancara untuk para guru dan orang tua untuk mengetahui kendala pembelajaran secara daring. Dengan adanya pembelajaran secara daring ini ditemukan beberapa kendala seperti minimnya pemahaman teknologi untuk para guru maupun orang tua, pengeluaran kuota yang juga tidak sedikit, juga terjadinya penambahan waktu kerja bagi orang tua, dampak sosialisasi antar siswa yang berkurang, dan jam kerja para guru yang justru menjadi tanpa batas karena harus selalu berkomunkasi dan berkonsolidasi dengan orang tua, guru lain, dan kepala sekolah.?

Undang-Undang Nomor 20 tahun 2003 dalam sistem pendidikan nasional pasl 45 ayat 1, yang menyatakan: "Setiap satuan pendidikan formal dan nonformal menyediakan sarana dan prasarana yang memenuhi keperluan pendidikan sesuai dengan pertumbuhan dan perkembangan potensi fisik, kecerdasan intelektual, social emosional, dan kejiwaaan peserta didik." (UU No.2 Tahun 2003). Sebagaimana dijelaskan dalam Undang-Undang tersebut, sarana dan prasarana harus disesuaikan dengan tumbuh kembang pada potensi fisik atau tubuh, kecerdasan intelektual, sosial emosional, dan kejiwaaan para murid. ${ }^{8}$ Dalam masa wabah COVID-19 ini tidak hanya menuntut guru namun pemerintah untuk terus berfikir kreatif dan mengelola dengan baik pembelajaran yang harus terus berjalan meskipun tanpa tatap muka atau bertindak kreatif dengan model pendidikan era pandemi ini. ${ }^{9}$ Pengelolaan meliki kata dasar dari "kelola" secara Kamus Besar Bahasa Indonesia Kontemporer (KBBI) pengolalaan merupakan memimpin, mengendalikan, mengatur, dan

5 Astuti, “Analisis Peran Orang Tua Dalam Meningkatkan Hasil Belajar Siswa Kelas X SMK Muhammadiyah Pontianak." Dasar."

${ }^{6}$ Dewi, "Dampak Covid-19 Terhadap Implementasi Pembelajaran Daring Di Sekolah

7 Agus Purwanto et al., "Studi Eksploratif Dampak Pandemi COVID-19 Terhadap Proses Pembelajaran Online di Sekolah Dasar" Jurnal of Education, Psychology and Counseling Vol. 2 No.1 (2020): 12.

8 Fitria Fauziah Hasanah dan Erni Munastiwi, "Pengelolaan Pendidikan Karakter Religius Melalui Metode Pembiasaan di Taman Kanak-Kanak” 4, no. 1 (2019): 12.

${ }^{9}$ Hasanah dan Munastiwi. Hlm. 37 
mengusahakan atau menyelenggarakan agar lebih baik dan maju serta bertanggung jawab atas perkerjaannya. Pengelolaan membutuhkan kerjasama dengan berbagai pihak untuk mencapai tujuan pelaksanaan organisasi tertentu dan dibarengi dengan adanya pengawasan dalam pelaksanaannya. ${ }^{10}$

Selain pengelolaan, penggunaan internet sangat penting di masa pandemi ini. Bagaimana internet memudahkan beragam akses situs sesuai kebnutuhan dan jasa, tak luput dalam bidang pendidikan. ${ }^{11}$ E-education atau bisa juga disebut pendidikan elektronik adalah sebutan untuk penggunaan IT (Informasi dan Teknologi) di bidang pendidikan. Akses informasi menggunakan internet yang semakin mudah digunakan Pesatnya perkembangan Informasi Teknologi terutama internet yang mengalami perkembangan informasi yang lebih baik terutama dalam layanan lembaga pendidikan. ${ }^{12}$ Sedangkan pendidikan dapat diartikan sebagai komunikasi, Orang tua dan Guru. Melihat ketiga faktor penting dalam menunjang pendidikan, pemerintan memberikan alternatif atau saran dalam proses pembelajaran di masa pandemi ini, yaitu dengan pendidikan elektronik yang dapat memfasilitasi pembelajaran tatap muka tanpa harus keluar rumah. Dengan kecanggihan elektronik yang semakin meningkat setiap jaman, terutama di masa pandemi ini demi memenuhi fasilitas komunikasi jarak jauh, menuntut orang tua untuk terus memantau pembelajaran anaknya. Karena peran orang tua adalah bentuk kompleks dari pengharapan terhadap caranya bertanggung jawab pada keluarga.

Dalam sebuah keluarga orang tua memiliki peran yang sangat penting dalam membantu pertumbuhan dan perkembangan anak, termasuk dalam proses pembelajaran. Orang tua menjadi pilar utama dan pertama dalam pendidikan sebelum anak terjun ke dunia luar. Bukan hanya sebagai penunjuk atau pembimbing namun lebih pada memberikan contoh bagi anak-anak mereka. Karena itu orang tua adalah model mereka. ${ }^{13}$ Selain itu, orang tua juga bertanggung jawab dalam memberikan pembelajaran yang baik pada anak mereka.

Berangkat dari berbagai persoalan yang dialami para orang tua maupun guru dalam melakasanakan pembelajaran daring di era pandemi ini, maka peneliti akan melakukan kajian tentang problematika orang tua dalam mendampingi anak pada pembelajaran era pandemi covid 19. Penelitian ini menggunakan pendekatan studi kepustakaan. Dalam kontek ini peneliti dalam

${ }^{10} \mathrm{KBBI}$

11 Dela Agustiah, Taty Fauzi, dan Erfan Ramadhani, "Dampak Penggunaan Media Sosial Terhadap Perilaku Belajar Siswa," Islamic Counseling: Jurnal Bimbingan dan Konseling Islam 4, no. 2 (30 November 2020): 181-90, https://doi.org/10.29240/jbk.v4i2.1935.

12 Yulita Pujilestari, "Dampak Positif Pembelajaran Online Dalam Sistem Pendidikan Indonesia Pasca Pandemi Covid-19” 4, no. 1 (2020): 8. Hlm. 52-53.

${ }^{13}$ Astuti, "Analisis Peran Orang Tua Dalam Meningkatkan Hasil Belajar Siswa Kelas X SMK Muhammadiyah Pontianak." 
menjawab masalah penelitian dilakuakn dengan mengumpulkan informasi mellaui dokumen, buku, majalah, juga berita dengan berfokus pada informasi terkait permasalahan pembelajaran pada masa pandemi COVID-19. Peneliti berfokus kepustakaan yang berpusat pada pembinaan pembelajaran dalam era pandemi COVID-19. Pendekatan ini digunakan untuk mengeksplorasi topik dan fenomena yang ada sesuai tujuan penelitian.

\section{Hasil dan Pembahasan}

\section{Problematika Pembelajaran di Masa Pandemi pada Sudut Pandang Media}

Seluruh negeri telah terkena dampak dari pandemi COVID-19 ini. Baik dari dalam maupun luar negeri kini memberlakukan sistem Lockdown. Melalui kompas.com dapat diketahui dampak pandemi ini tidak hanya pada negatif saja, namun terdapat dampak positif, yang mana dilarangnya kegiatan di luar ruangan ini memjadi kesempatan para keluarga berkumpul utuh. Dampak negatif juga dapat dirasakan dalam dunia pendidikan dimana pembelajran yang dilakukan di dalam rumah, menjadikan para anak mengeluhkan cepat bosan karena minimnya fasilitas dan menutup ruang gerak anak, ditambah dengan kurangnya kemampuan orang tua dalam menggantikan guru di sekolah. ${ }^{14}$ Banyak dari para orang tua yang juga melakukan pekerjaan dari rumah (Work From Home), sementara itu mereka juga bertanggung jawab dalam mendampingi pembelajaran anak. Kurangnya kemampuan membuat beberapa orang tua mengalami stress karena dituntut untuk mahir dalam segala kegiatan dan multitasking. ${ }^{15}$

Peran seorang ibu juga menuntut untuk multitasking, terutama dengan urusan keluarganya. Pemapaparan Times Indonesia mengenai para ibu yang kini dituntut untuk memaksimalkan peran, karena era pandemi ini menuntut pembelajaran untuk dilakukan di rumah dengan pendampingan orang tua dengan mengerahkan segala macam model pengasuhan, terutama mengasuh anak di usia PAUD dan SD. ${ }^{16}$ Tidak hanya ibu saja yang berperan dalam pembelajaran anak. Baik kedua orang tua harus terus menjaga emosi yang mana lebih sering terjadi konflik. Dengan begitu, para orang tua dianjurkan untuk

14 Artikel ini telah tayang di Kompas.com dengan judul "Cegah Covid-19, Ini Tantangan Orangtua Dampingi Anak Saat Diam di Rumah " pada 02/04/2020, 12:30 WIB. https://nasional.kompas.com/read/2020/04/02/12303441/cegah-covid-19-initantangan-orangtua-dampingi-anak-saat-diam-di-rumah.

${ }^{15}$ Mieke Beth Thomeer, Corinne Reczek, dan Debra Umberson, "Gendered Emotion Work around Physical Health Problems in Mid- and Later-Life Marriages," Journal of Aging Studies 32 (Januari 2015): 12-22, https://doi.org/10.1016/j.jaging.2014.12.001.

16 Artikel ini telah tayang di timesindonesia.co.id dengan judul "Dampak Covid-19 Memunculkan Monster Pendidikan di Rumah" pada Jumat. 27 Maret 2020, 00:25. https://www.timesindonesia.co.id/read/news/259829/dampak-covid19-memunculkan- 
dapat memahami karakter anak, untuk menunjang pembelajaran di rumah agar tepat sasaran. Sayangnya tidak melulu belajar di dalam rumah menyenangkan untuk anak. Karena pembelajaran di rumah juga merupakan salah satu tantangan bagi orang tua. Seperti hasil wawancara beberapa ibu terkait keadaan saat ini dalam Republika.com. Salah satunya yang mengeluh dengan banyaknya tugas selama masa pandemi. Dalam wawancara beliau berkata: "Ini anak-anak belajar di rumah jadi orangtua yang sibuk. Aku stres banget nih.. jadi pengawas."

Tidak hanya satu atau dua orang yang mengeluh, bahwa tidak semua orang tua dapat memberikan fasilitas pembelajaran terbaik untuk anak. Keluhan lainnya terus datang dari masa pembelajaran di rumah ini. Seperti bagaimana para orang tua yang mengeluh tentang masalah gawai atau ponsel. Tidak semua anak dapat dan diperbolehkan memegang ponsel mereka sendiri, menyebabkan beberapa orang tua harus berbagi ponsel dengan anak mereka. Keadaan seperti ini juga sering menyebabkan beberapa ponsel mengalami kelebihan kapasitas sehingga berujung hang atau eror. Keluhana lainnya juga datang karena susahnya pembagian waktu. Disaat para orang tua seharusnya bekerja dari rumah, namun tersita karena harus mendampingi anak belajar di waktu yang bersamaan. ${ }^{17}$

Keluhan tentang bagaiamana proses pembelajaran di era pandemi terus berdatangan bahkan dari luar negeri. Liputan6.com mengkaji penelitian yang diunggah laman web Universitas Michigan (2020) menjelaskan bagaimana stress dan ketidakpastian yang dialami orang tua, merupakan beban fisik dan psikologis yang diakibatkan semasa pandemi ini, salah satunya terjadi karena kegelisahan anak-anak dalam pembelajaran yang mengganggu para orang tua. Xinhua juga menjelaskan terdapat pengaruh antara kesehatan mental dan kesejahteraan pola asuh dengan keadaan ekonomi selama pandemi COVID-19 ini. Hasil dari penelitiannya $11 \%$ orang tua mengakui telah melakukan pemukulan terhadap anak mereka, terkadang menampar selama masa pandemi ini. Diprediksi presentasenya juga akan terus naik seiring panjangnya pandemi ini. Selain kekerasan, beberapa anak 4 dari 10 dibentak dengan nada tinggi oleh orang tuanya. Wawancara terus dilakukan untuk mencari perbandingan dari sebelum pandemi, setidaknya ada $19 \%$ orang tua terbukti membentak anak mereka semenjak pandemi, dengan 15\% orang tua menghukum anak mereka lebih berat semenjak pandemi. Shawn Lee selaku direktur UM Parenting di Context Research Lab. mengatakan :"Mengingat bahwa data ini diambil di periode awal pemberlakuannya Lockdown sebagai usaha pemutus pandemik COVID-19, kita memprediksi akan adanya peningkatan seiring waktu ketika kondisi ekonomi memburuk dan juga tingkat stress para orang tua meningkat" Berita buruk terus datang seiring waktu, namun bukan berarti tidak ada harapan. Setidaknya 88\%

17 Artikel ini telah tayang di REPUBLIKA.CO.ID dengan judul " Murid Belajar di Rumah: Stres Orang Tua dan Kendala Lainnya" pada Rabu, 18 Maret 2020, 13:23. https://republika.co.id/berita/q7dlrn409/murid-belajar-di-rumah-stres-orang-tua-dan-kendalalainnya 
orang tua menginformasikan, terjadi hubungan yang justru semakin membaik, seperti menunjukkan kasih sayang lebih sering antara anak dan orang tua selama masa pandemi ini. ${ }^{18}$

\section{Peran Orangtua dalam Pembelajaran}

Pengasuhan adalah proses mendukung fisik, emosi, sosial dan perkembangan anak sejak bayi hingga dewasa. Sedangkan parenting adalah sesuatu yang mencakup apa yang harus diperbuat para orang tua maupun para pengasuh dalam menjalankan tugas dan tanggung jawabnya menuju perkembangan anak. ${ }^{19}$ Sedangkan pembelajaran anak memerlukan pengawasan karena pengawasan menjadi kunci keberhasilan dalam pendidikan. Pengawasan sendir merupakan standar, pengukuran pelaksanaan, dan pengambilan tindakan secara korektif. Sedangkan pengawasan adalah sebuah rencana dapat terealisasi, mengarahkan, dan memperbaiki semua komponen yang terlibat dalam realisasi perencanaan, sehingga sebuah perencanaan dapat terealisasi dengan optimal. ${ }^{20}$

Dalam penelitian yang dilakukan Rosleny pada regulasi emosi, stress, dan kesejahteraan psikologis pada ibu yang melakukan Work From Home ketika masa COVID-19 menunjukkan bahwa regulasi emosi berperan mengalahkan stress. Regulasi emosi yang tepat dapat memberikan ketenangan psikologis bagi ibu pekerja sehingga berpengaruh terhadap pengambilan keputusan yang sesuai. ${ }^{21}$ Serta studi yang dilakukan oleh Erpiana menjelaskan bahwa kesabaran, keteladanan, rasa cinta, dan konsistensi yang tinggi dalam mengajarkan kebaikan menjadi faktor psikologis lainnya yang wajib dimiliki baik seorang $\mathrm{Ibu}^{22}$ maupun juga ayah, sebagai orang tua.

\section{Pembelajaran di Era Pandemi}

Pelaksanaan pembelajaran di era pandemi dilakukan dengan cara tidak melakukan tatap muka berdasarkan prinsip social distancing dan phsical distancing. Pengembangan sekolah sebagai tempat belajar dan pembelajaran tidak dapat dipisahkan sebagi tempat belajar dan pembelajaran tidak dapat dipisahkan dari

${ }^{18}$ Artikel ini telah tayang Liputan6.com, Chicago dengn judul "Studi Ungkap Orangtua dan Anak Sering Konflik Selama Pandemi Corona COVID-19" pada 02 April 2020, 09:01 WIB. https://www.liputan6.com/global/read/4216978/studi-ungkap-orangtua-dan-anak-seringkonflik-selama-pandemi-corona-covid-19\#.

19 Thorik Aziz, Ria Astuti, dan Erni Munastiwi, "Parenting Program To Improve Quality Learning In Institutions Of Early Childhood Education (Case At Tk At-Taufiqiyah Aengbajaraja Bluto Madura)," JURNAL INDRIA (Jurnal Ilmiah Pendidikan Prasekolah Dan Sekolah Awal) 3, no. 2 (10 September 2018): 141-54, https://doi.org/10.24269/jin.v3n2.2018.pp141154.

${ }^{20}$ Hasanah dan Munastiwi, "Pengelolaan Pendidikan Karakter Religius Melalui Metode Pembiasaan di Taman Kanak-Kanak."

${ }^{21}$ Rosleny Marliani dkk., "Regulasi Emosi, Stres, dan Kesejahteraan Psikologis: Studi Pada Ibu Work from Home dalam Menghadapi Pandemi COVID-19,” t.t., 12.

${ }^{22}$ Marliani dkk. 
kegiatan integrasi teknologi di sekolah. Untuk mewujudkan mutu pembelajaran membutuhkan profesionalisme guru. Hal ini juga berpengaruh pada pelaksaan pembelajaran dalam kondisi pandemi COVID-19 seperti saat ini. Diharapkan para guru memenuhi kemampuan sebagai salah satu pengkonstruksi keberhasilan pembelajaran di era pandemi ini. Sehingga dalam pengembangan mutu belajar perlu kerangka kerja untuk mengembangkan teknologi, pedagogi, dan konten pembelajaran. ${ }^{23}$ Sedangkan fasilitas IT sangat berpengaruh juga pada bagaimana pemerintah mengalokasikannya dana untuk melengkapi fasilitas IT di banyak institut pendidikan. ${ }^{24}$ Masih belum meratanya dana ke daerah-daerah kecil membuat pengetahuan tentang teknologi berbeda antara dengan bagian perkotaan yang kondusif bagi investasi swasta bidang pendidikannya.

Proses komunikasi dilakukan untuk membangun pemahaman antara para guru bersama kepala sekolah dengan berbagi kebiasaan mengajar untuk menjembatani ide-ide agar lebih mudah tersalurkan antara guru dan kepala sekolah. Selain hubungan antara para guru dengan kepala sekolah, komunikasi pembelajaran juga membawa orang tua ikut berperan di dalamnya, terutama di masa pandemi ini dimana berlakunya pembelajaran secara online, komunikasi yang baik dengan oarng tua sangat dibutuhkan agar pembelajaran terus berjalan. Selain membutuhkan komunikasi, pembelajaran era pandemi juga mengandalkan teknologi. Sedangkan menurut Lantip dan Rianto teknologi informasi merupakan bagian dari ilmu pengetahuan dan bidang informasi berbasis komputer yang mana perkembangannya sangat pesat saat ini, tidak sebanding dengan penggunannya yang baru memasuki tahap pengembangan, terutama penerapan IT dalam bidang pendidikan. ${ }^{25}$ Maka tak jarang banyak orang tua murid mengalami kesulitan dalam memahami alur atau cara pakai pembelajaran berbasis informasi teknologi, sedanhkan era pandemi ini pengetahuan tentang teknologi sangat dibutuhkan untuk menunjang pendidikan yang baik.

\section{Problematika Orang Tua dalam Pembelajaran Era Pandemi COVID-19}

Berdasarkan sumber yang didapat oleh peneliti terkait pembelajaran di era pandemi ini peneliti dapat mengklasifikasikan menjadi 3 bagian, yakni:

${ }^{23}$ Henry Praherdhiono dkk., Implementasi Pembelajaran Di Era Dan Pasca Pandemi COVID-19, t.t.

24 Pujilestari, "Dampak Positif Pembelajaran Online Dalam Sistem Pendidikan Indonesia Pasca Pandemi COVID-19."

25 Pujilestari, "Dampak Positif Pembelajaran Online Dalam Sistem Pendidikan Indonesia Pasca Pandemi COVID-19.”. 


\section{Tabel. 1 Masalah pokok yang dialami orang tua dalam pendampingan belajar}

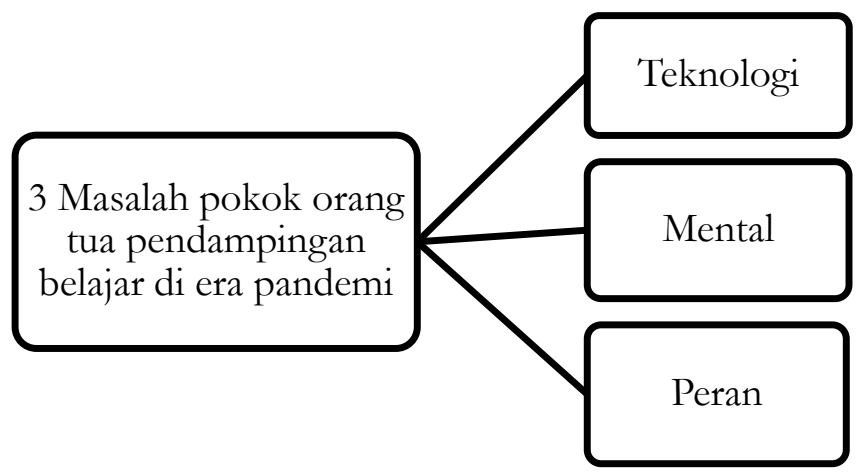

Melihat pada tabel di atas dapat dipahami jika kegiatan belajar yang dilakukan di rumah selama masa pandemi ini justru menghapus batasan pekerjaan kantor dengan pekerjaan rumah bagi orang tua. Jika sebelum pandemi pekerjaan kantor dapat diselesaikan di luar ruma, kini pekerjaan itu bercampur dengan pekerjaan rumah. Termasuk dalam mengawasi pembelajaran anak. Sehingga perlunya komunikasi antara guru dan orang tua, untuk saling bahu membahu memantau perkembangan pendidikan anak di rumah.

Teknologi terus berkembang seiring perubahan zaman, terutama di zaman modern ini pembelajaran tatap muka masih bisa terjadi tanpa perlu keluar rumah untuk menghindari penularan wabah COVID-19. Sama halnya perkembangan teknologi di luar Indonesia yang berkembang pasar, di Indonesia sendiri penggunaan teknologi juga semakin berkembang. Sayangnya perkembangan teknologi ini tidak didukung dengan pemahaman cara penggunaan, terutama para pengajar juga masih banyak yang lemah dalam ilmu teknologi. Tidak hanya kemampuan personal dalam memahami teknologi, beberapa daerah di Indonesi juga terkendala geografis. Beberapa tempat yang tak terjangkau sinyal internet mempersulit pembelajaran online. Beberapa orang tua mengeluh dengan pengeluaran yang tidak bisa dibilang sedikit untuk kebutuhan kuota internet, di saat harga bahan pangan juga tidak murah di era pandemi. Selain masalah sinyal, beberapa mengeluh dengan kondisi ponsel yang menjadi eror karena kelebihan kapasitas.

Berdasarklan data lapangan yang dilakukan Agustiah terdapat 25\% siswa belum memahami cara menggunakan internet dengan baik, dikarenakan kurangnya pemahaman manfaat dari penggunaan internet. Banyak dari mereka mengabaikan tugas rumah dan sibuk bermain game maupun situs lainnya. ${ }^{26}$ Sehingga perlunya bimbingan orang tua dalam penggunaan internet saat masa belajar online. Tidak hanya kurangnya pengetahuan pemanfaatan internet,

${ }^{26}$ Agustiah, Fauzi, dan Ramadhani, "Dampak Penggunaan Media Sosial Terhadap Perilaku Belajar Siswa." 
beberapa tempat di Indonesia bahkan tidak mendapat sinyal internet. Berdasarkan hasil badan pusat statisti tahun 2018 terdapat perbandingan besar dalam penggunaan internet antara perkotaan seperti DKI Jakarta dengan $89,04 \%$ pengguna sedangkan daerah terpencil seperti papua hanya 29,50\% pengguna. Hal ini disebabkan daerah topografi Indonesia yang berupa kepulauan dan pegunungan. Dan kebanyakan jangkauan 4G berada pada pulau Jawa, karena distribusi yang tidak merata melihat prioritas pasar. ${ }^{27}$ Selain kebutuhan fasilitas di rumah, digital seperti laptop dan jaringan internet sangat dibutuhkan di sekolah sebagai sarana dan prasarana yang dipakai guru untuk memenuhi administrasi sekolah dan penyelesaian tugas materi ajar. ${ }^{28}$

Mental orang tua sangat berpengaruh dalam pembelajaran di rumah. Jika tidak terkontrol atau stress terutama pada orang tua, dapat menjadikan anak sebagai pelampiasan stress. Pelampiasan dapat berupa kekeras fisik maupun verbal. Berdasarkan laporan yang media beritakan, terdapat beberapa orang tua yang kemudian menjadi stress dan memburuknya kondisi Mental, yang diakibatkan ketidakpastian kondisi pandemi COVID-19 yang semakin tidak pasti berakhirnya. Ketika semua pekerjaan kantor dialihkan ke rumah (Work From Home) mengakibatkan penumpukan pekerjaan yang tercampur dengan pekerjaan rumah. Selain penumpukan pekerjaan beberapa dari orang tua juga terancam kehilangan pekerjaan. Sebagian orang tua yang memiliki kondisi mental yang buruk melakukan hal yang kurang pantas pada anak mereka sebagai pelampiasan. Tidak hanya Indonesia menurut Imperial College bagian dunia lainnya juga mengalami ketidakstabilan antara pendapatan masuk dengan populasi yang merugikan.

Sedangkan di saat pandemi COVID-19 anak memerlukan pengaruh utama dari faktor psikologis ${ }^{29}$ yakni motivasi belajar. Dorongan dan memotivator anak dengan kasih sayang secara berkelanjutan, tak lupa memberikan suasana pembelajaran yang nyaman untuk pembelajaran memberikan tantangan baru bagi orang tua di saat ini. Kemunduran ekonomi selama pandemi, memberikan efek seperti loncatan keluarga menjadi lebih mendekati pada kemelaratan. Dampak ekonomi yang berpadu pada COVID-19 itu sendiri, akan memperburuk pengalaman trauma selama waktu pandemi ini. ${ }^{30}$

${ }^{27}$ Nadia Fairuza Azzahra, "Mengkaji Hambatan Pembelajaran Jarak Jauh di Indonesia di Masa Pandemi Covid-19," Indonesia?"

28 M.Rizki Nasution, "COVID-19 Tidak Menjadi Hambatan Pendidikan Di

${ }^{29}$ Munirwan Umar, "Peranan Orang Tua Dalam Peningkatan Prestasi Belajar Anak," Jurnal Edukasi: Jurnal Bimbingan Konseling 1, no. 1 (1 Januari 2015): 20-28, https://doi.org/10.22373/je.v1i1.315.

30 Sara Schjolberg Marques dan Ruth Braidwood, "Impact of the Coronavirus Lockdown on Older Adolescents Engaged in a School-Based Stress Management Program: Changes in Mental Health, Sleep, Social Support, and Routines," Children \& Schools, no. cdab006 (5 April 2021), https://doi.org/10.1093/cs/cdab006. 
Keadaan ini membuat beberapa orang tua tak dapat mengontrol stress mereka sehingga mempengaruhi pola asuh dan pembimbingan belajar pada anak. Tak jarang anak juga ikut mengalami stress.

Peran orang tua menjadi pengawas maupun pendamping tumbuh kembang anaknya, selain itu juga berperan dalam menghidupi keluarga dengan bekerja. Semenjak wabah pandemi ini melanda banyak orang tua yang mengeluh hingga stress dalam mengelola waktu, yang mana semuanya dikerjakan di rumah. Tidak semua orang tua pandai dalam mendampingi pembelajaran anaknya. Mulai dari memahami soal yang diberikan guru hingga menjelaskannya pada anak adalah tantangan yang cukup berat bagi beberapa orang tua sehingga terkesan memaksa. Termasuk yang mana tidak memiliki latar belakang pendidikan, sehingga timbul pemahaman dengan cara yang berbeda antara maksud guru dan hasil yang dipahami orang tua. Salah satu mengetahui maksud guru dengan melihat dan terbiasa dengan guru mengajar. Setiap guru memiliki caranya sendiri dalam mengajar, dan ini hanya bisa dipahami oleh anak yang mana sering melihatnya di kelas saat sebelum pemberlakuan Lockdown ini.

Pendidikan yang baik tidak hanya berkaitan dengan nilai, namun juga pendidikan ialah refleksi dari seorang individu yang memberikan respek yang seimbang pada sebuah perbedaan sosial. Bagaimana anak memahami satu dengan lainnya dan bekerja bersama. ${ }^{31} \mathrm{Hal}$ ini juga menjadi peran orang tua untuk tetap memberikan arahan bagaimana dalam berinteraksi sosial dengan baik di saat pembatasan sosial dilakukan. Karena orang tua merupakan penanggung jawab utama ${ }^{32}$ dalam pendidikan dan menentukan masa depan anaknya, baik secara formal maupun non-formal.

Keberlangsungan pandemi COVID-19 ini menjadikan pembelajaran di sekolah beralih menjadi pembelajaran mandiri atau via online. Dimana para guru tidak bisa bertatap muka secara langsung kepada para murid, melainkan hanya sekedar memberikan tugas yang disampaikan lewat orang tua. Tugas guru digantikan kepada orang tua yang sebenarnya juga memiliki pekerjaan lain selain mendampingi anak belajar. Ketidak efektifan pembagian waktu sering kali membuat para orangtua merasa stres yang kemudian berpengaruh dalam memperlakukan anak-anak mereka. Walaupun beberapa media melaporkan kekerasan yang dilakukan para orangtua selama masa Lockdown dan pendampingan belajar anak di rumah. Diantaranya masih ada yang justru mempererat kekeluargaan.

Perbedaan pembelajaran pada anak-anak selama masa pandemi ini karena masalah fasilitas. Baik secara sinyal maupun dari teknologi yang

${ }^{31}$ Jia Song, "Inclusive Education in Japan and Korea - Japanese and Korean Teachers' Self-Efficacy and Attitudes Towards Inclusive Education," Journal of Research in Special Educational Needs 16, no. S1 (2016): 643-48, https://doi.org/10.1111/1471-3802.12324.

32 Munirwan Umar, "Peranan Orang Tua Dalam Peningkatan Prestasi Belajar Anak" 
digunakan seperti ponsel masih kurang umum digunakan terutama untuk pembelajaran anak-anak. Baik secara fasilitas yang kurang memadai dan minimnya semangat belajar anak.

\section{Penutup}

Hasil dari penelitian ini ditemukan 3 hal pokok sebagai problematika utama dalam mendampingi pembelajaran di era pandemi ini. Diantara ke tiganya ialah ada: a) Teknologi, b) Mental, dan c) Peran. Ketiga pokok ini saling terhubung, walaupun saling terhubung bukan berati dapat disimpulkan menjadi satu masalah dengan satu solusi. Sehingga perlunya survei lebih mendalam lagi, terutama di Indonesia yang mana memiliki banyak daerah-daerah kecil berkemungkinan memiliki masalah yang lebih kompleks lagi. Ketiga permasalahan ini terhubung, sebagaimana teknologi mempengaruhi mental orang tua yang harus kembali mempelajari teknologi. Selain harus mempelajari hal baru, karena teknologi terus berkembang, para orang tua juga khawatir pada anak-anak mereka yang belum paham dengan pengoperasian ponsel, jika mereka diberikan ponsel secara individu. Akibatnya para orang tua harus berbagai penggunaan ponsel dengan anak mereka. Tak jarang dari ponsel mereka yang kemudia rusak karena menerima kapasitas berlebihan dari kantor dan sekolah anak mereka. Sehingga para orang tua perlahan tertekan secara mental. Belum lagi tidak semua orang tua pintar dalam mengajar. Selain masalah mental, peran orang tua juga semakin berlipat. Dimana mereka berkewajiban untuk tetap bekerja dari rumah (Work From Home) dan ditumpuk dengan tugas anaknya yang terus menggunung tanpa batas karena belajar dari rumah dengan jam belajar lebih lama ketimbang berangkat ke sekolah. Hal ini dikarenakan jam belajar mengajar menjadi tak terbatas dengan peniadaan sekolah.

\section{Daftar Pustaka}

Agustiah, Dela, Taty Fauzi, dan Erfan Ramadhani. "Dampak Penggunaan Media Sosial Terhadap Perilaku Belajar Siswa." Islamic Counseling : Jurnal Bimbingan dan Konseling Islam 4, no. 2 (30 November 2020): 181-90. https://doi.org/10.29240/jbk.v4i2.1935.

Astuti, Dewi. "Analisis Peran Orang Tua Dalam Meningkatkan Hasil Belajar Siswa Kelas X SMK Muhammadiyah Pontianak," t.t., 8.

Astuti, Ria, dan Erni Munastiwi. "Pendidikan Anak Usia Dini Berbasis Tauhid (Studi Kasus Paud Ababil Kota Pangkalpinang)." Al-Mudarris (Jurnal Ilmiah Pendidikan Islam) 1, no. 2 (8 April 2019): 1-19. https://doi.org/10.23971/mdr.v1i2.1011.

Aziz, Thorik, Ria Astuti, dan Erni Munastiwi. "Parenting Program To Improve Quality Learning In Institutions Of Early Childhood Education (Case 
At Tk At-Taufiqiyah Aengbajaraja Bluto Madura).” Jurnal Indria (Jurnal Ilmiah Pendidikan Prasekolah Dan Sekolah Awal) 3, no. 2 (10 September 2018): $141-54$. https://doi.org/10.24269/jin.v3n2.2018.pp141-154.

Azzahra, Nadia Fairuza. "Mengkaji Hambatan Pembelajaran Jarak Jauh di Indonesia di Masa Pandemi Covid-19." Center for Indonesian Policy Studies, Ringkasan Kebijakan, no. 2 (Mei 2020): 9.

Baswedan, Anies R. "Gawat Darurat Pendidikan di Indonesia." 2014. Presentasi Kementerian Pendidikan dan Kebudayaan Republik Indonesiat.t.t.

Darojatil'Ulya, Faizatud. "Strategi Pengembangan Kreativitas Anak Usia Dini Di Taman Kanak-Kanak Mardisunu Tanjungsari Tulungagung,” 2019.

Dewi, Wahyu Aji Fatma. "Dampak Covid-19 Terhadap Implementasi Pembelajaran Daring Di Sekolah Dasar" 2, no. 1 (2020): 7.

Hasanah, Fitria Fauziah, dan Erni Munastiwi. "Pengelolaan Pendidikan Karakter Religius Melalui Metode Pembiasaan di Taman Kanak-Kanak" 4, no. 1 (2019): 12.

Holis, Ade. "Belajar Melalui Bermain untuk Pengembangan Kreativitas dan Kognitif Anak Usia Dini.” Jurnal Pendidikan UNIGA 10, no. 1 (2017): 23-37.

. "Peranan Keluarga/Orang Tua Dan Sekolah Dalam Mengembangkan Kreativitas Anak Usia Dini.” Jurnal Pendidikan UNIGA 1, no. 1 (2017): $22-43$.

Marliani, Rosleny, Endin Nasrudin, Rika Rahmawati, dan Zulmi Ramdani. "Regulasi Emosi, Stres, dan Kesejahteraan Psikologis: Studi Pada Ibu Work from Home dalam Menghadapi Pandemi COVID-19," t.t., 12.

Marques, Sara Schjølberg, dan Ruth Braidwood. "Impact of the Coronavirus Lockdown on Older Adolescents Engaged in a School-Based Stress Management Program: Changes in Mental Health, Sleep, Social Support, and Routines." Children \& Schools, no. cdab006 (5 April 2021). https://doi.org/10.1093/cs/cdab006.

M.Rizki Nasution. "Covid-19 Tidak Menjadi Hambatan Pendidikan Di Indonesia?," 2020. https://doi.org/10.13140/RG.2.2.28543.36005/1.

Munandar, Utami. Pengembangan Kreativitas Anak Berbakat. Jakarta: Rineka Cipta, 2004.

Munastiwi, Erni. "Manajemen Ekstrakurikuler Pendidikan Anak Usia Dini (PAUD)." MANAGERIA: Jurnal Manajemen Pendidikan Islam 3, no. 2 $(25$ Januari 2019): 369-80. https://doi.org/10.14421/manageria.2018.32-09. 
—. "Manajemen Model Pembinaan Kelompok Guru Paud Model 'MultiWorkshop,"” t.t., 10.

Munastiwi, Erni, dan Marfuah Marfuah. "Islamic Education in Indonesia and Malaysia: Comparison of Islamic Education Learning Management Implementation." Jurnal Pendidikan Islam 8, no. 1 (28 Agustus 2019): 1-26. https://doi.org/10.14421/jpi.2019.81.1-26.

Nurhati, Iis. "Pola Pengasuhan Dalam Pengembangan Kreativitas Peserta Didik Di Rumah Pintar Efata Semarang." PhD Thesis, Universitas Negeri Semarang, 2017.

Praherdhiono, Henry, Eka Pramono Adi, Yulias Prihatmoko, Nunung Nindigraha, Yerry Soepriyanto, Henny Indreswari, dan Herlina Ike Oktaviani. IMPLEMENTASI PEMBELAJARAN DI ERA DAN PASCA PANDEMI COVID-19, t.t.

Pujilestari, Yulita. "Dampak Positif Pembelajaran Online Dalam Sistem Pendidikan Indonesia Pasca Pandemi Covid-19" 4, no. 1 (2020): 8.

Purwanto, Agus, Rudy Pramono, Masduki Asbari, Priyono Budi Santoso, Laksmi Mayesti, Choi Chi Hyun, dan Ratna Setyowati Putri. "Studi Eksploratif Dampak Pandemi COVID-19 Terhadap Proses Pembelajaran Online di Sekolah Dasar," t.t., 12.

Rachmawati, Yeni. Strategi Pengembangan Kreativitas Pada Anak. Prenada Media, 2012.

Song, Jia. "Inclusive Education in Japan and Korea - Japanese and Korean Teachers' Self-Efficacy and Attitudes Towards Inclusive Education." Journal of Research in Special Educational Needs 16, no. S1 (2016): 643-48. https://doi.org/10.1111/1471-3802.12324.

Sutarto, S., Sari, D. P., \& Fathurrochman, I. (2020). Teacher strategies in online learning to increase students' interest in learning during COVID-19 pandemic. Jurnal Konseling dan Pendidikan, 8(3), 129-137.

Thomeer, Mieke Beth, Corinne Reczek, dan Debra Umberson. "Gendered Emotion Work around Physical Health Problems in Mid- and Later-Life Marriages." Journal of Aging Studies 32 (Januari 2015): 12-22. https://doi.org/10.1016/j.jaging.2014.12.001.

Umar, Munirwan. "Peranan Orang Tua Dalam Peningkatan Prestasi Belajar Anak.” JURNAL EDUKASI: Jurnal Bimbingan Konseling 1, no. 1 (1 Januari 2015): 20-28. https://doi.org/10.22373/je.v1i1.315. 